\title{
The politics of incremental change: institutional change in old-age pensions and health care in Germany
}

\author{
Karen M. Anderson
}

Published online: 28 July 2015

(C) Institut für Arbeitsmarkt- und Berufsforschung 2015

\begin{abstract}
This paper analyzes policy shifts in two core welfare state programs in Germany: old-age pensions and health care. Both programs are prototypes of Bismarckian/ conservative program design (benefits are based on occupational and family status; financing is based on payroll contributions, and administration is based on corporatist arrangements) and both have experienced tremendous cost pressures because of demographic change and rising non-wage labor costs. A series of reforms since the late 1980s has reduced the generosity of benefits and aims to change the governance structures of both programs. Although the reforms include substantial benefit cuts, key conservative principles concerning benefit entitlement and financing remain largely untouched. In both programs, derived rights based on family status remain strong, and occupational fragmentation continues to characterize the overall structure of both systems. The paper argues that this pattern of institutional change is not new, but is typical of the politics of muddling through that has characterized the German system since its inception. I emphasize the impact of German political institutions, the structure of electoral competition, and the legacies of conservative social policy to explain the contemporary pattern of policy development.
\end{abstract}

Keywords Welfare state Germany $\cdot$ Health care Pensions · Institutionalism

K. M. Anderson ( $\square)$

Department of Sociology, Social Policy and Criminology,

University of Southampton,

SO17 1BJ Southampton, UK

e-mail: k.m.anderson@soton.ac.uk

\section{Die Politik der schrittweisen Veränderung: Institutioneller Wandel bei Altersrenten und Gesundheitsversorgung in Deutschland}

Zusammenfassung Dieser Artikel analysiert die Verschiebungen in zwei Säulen der Sozialversicherung: Altersrente und Gesundheitswesen. Beide Säulen sind Modelle konservativer, bismarckscher Prägung, und beide Systeme unterliegen aufgrund des demographischen Wandels und der steigenden Lohnnebenkosten einem enormen Kostendruck. Der Artikel hat drei zentrale Aussagen. Erstens haben Reformen zwar signifikante Veränderungen mit sich gebracht, jedoch die grundsätzlichen Strukturen und das Umverteilungsprofil des deutschen Wohlfahrtsstaats bleiben gleichwohl bestehen. Eine Reihe von Reformen hat die Großzügigkeit in der Leistungsverteilung gemindert und darauf abgezielt, die Leitungsstrukturen sowohl bei den Altersrenten als auch im Gesundheitswesen zu verändern. Die Einführung der Riesterrente im Jahr 2001 und des Gesundheitsfonds 2009 sollten als Reformen betrachtet werden, die die Anreize sowohl für die Versicherten als auch für die Leistungsträger neu gestalten. Die konservativen Grundprinzipien in Bezug auf Leistungsanspruch und Finanzierung bleiben weitgehend erhalten. Zweitens werden durch zwei Jahrzehnte der Reformen mehr Ungleichheiten erzeugt werden als es im alten System gab. Es gibt ein größeres $\mathrm{Ma} ß$ an Ausdifferenzierung bei den Altersrenten, und eine zunehmende Anzahl von Rentnern erhalten Leistungen, die nur knapp über der Armutsgrenze liegen. Die Annahmequoten bei der betrieblichen und der privaten Altersversorgung sind stark nach Einkommen geschichtet, ebenso wie der Wert der zur Förderung der Deckung verwendeten Steuerausgaben und Zuschüsse. Gleichermaßen werden die Reformen im Gesundheitswesen immer mehr Zahlungen aus eigener Tasche erfordern, was die niedrigen 
Einkommensgruppen härter treffen wird. Drittens will der Artikel nachweisen, dass dieses Muster der institutionellen Veränderung nicht neu, sondern für die Politik der kleinen Schritte, die den deutschen Wohlfahrtsstaat seit seinen Anfängen kennzeichnet, typisch ist.

\section{Theoretical perspectives on the German welfare state}

Germany occupies a distinct position in the welfare state literature because it is widely held to be the prototype of the "conservative" or "Bismarckian" welfare regime. Insurance-based cash benefits financed by payroll contributions cover the risks of unemployment, sickness, and old age for workers and their families, whereas social services are relatively underdeveloped relative to other affluent democracies. Social provision preserves status differences: social insurance pays benefits closely linked to previous earnings, with better-off groups (civil servants, self-employed professionals, and high income-earners) enjoying more generous social protection than the average wage-earner. Nevertheless, this fragmented system of social provision provides universal coverage for most social risks.

The dominant explanation of the postwar development of the German welfare regime is that it rests on a long period of consensus among political economic and societal actors about the basic contours of social provision (see, for example, Von Winter 1997). Christian Democratic dominance in legislative politics after WWII was accompanied both by the necessity of forming coalitions with the Liberal Party (FDP) or the Social Democratic Party (SPD), and the potential for veto in the Bundesrat, the upper chamber of parliament. Social policy was thus forged by competitive appeals by the CDU/CSU (Christian Democratic Union/Christian Social Union) and the SPD for the "pro-welfare vote", and by several compromises between the CDU/CSU and SPD at the expense of the FDP. These conditions ensured that social policy would not be based on radical redistribution or efforts to reshape society (as in Scandinavia). Instead, the development of social provision after WWII was marked by the resurrection of central principles of social policy developed in the late nineteenth century: Bismarckian social insurance for wage earners, special schemes for tenured civil servants, and an important role for civil society associations in the administration of social services like health care and education (Alber 1989; Esping-Andersen 1990).

Recent scholarship moves beyond the analysis of the political and social forces that have shaped the German welfare regime by highlighting the complementarities between social protection schemes and economic institutions. Scholars using the Varieties of Capitalism (VoC) framework highlight the economic functions of social protection in coordinated market economies (CMEs) like Germany
(Hall and Soskice 2001). Here, social policies are not just the currency of electoral politics, or mechanisms for insuring against social risks, but they are also key elements of an integrated set of socio-economic institutions in which employers and other economic actors use non-market forms of coordination to pursue their economic goals. In CMEs, for example, generous social insurance encourages workers to invest in skills, and uniform social insurance programs prevent employers from using fringe benefits to poach qualified workers from other firms (Estevez-Abe et al. 2001).

The institutional development of the German welfare regime in the past 3 decades is puzzling from the perspective of both literatures. Most analyses of social policy development since about 1990 emphasize the liberalization of both social insurance and social services (Streeck 2007; Trampusch 2009; Palier and Thelen 2010; Vail 2009). Although authors disagree about the extent of liberalization, the general trend is clear: recent reforms have weakened the breadwinner bias of social policy institutions; weakened corporatist administration of core programs like pensions and health care; introduced market mechanisms into core programs; and increased individuals' and the state's share of financing relative to contributions. Given the emphasis on policy stability in welfare state regime scholarship and the VoC literature, these shifts in social protection are surprising. Do fundamental changes in the post-war political consensus or the workings of the economic institutions crafted via the post-war settlement explain these shifts, or are other causal forces at work?

This article enters these debates by analyzing policy shifts in two core programs: old-age pensions and health care. Both programs are prototypes of Bismarckian/conservative program design, and both systems have experienced tremendous cost pressures because of demographic change and rising non-wage labor costs (Häusermann 2010). The article makes three central claims. First, reforms have indeed brought about significant change, but the basic structures and redistributional profile of the German welfare state nevertheless remain intact. A series of reforms has reduced benefit generosity, and have aimed to change the governance structures of both pension and health care programs. The introduction of voluntary private pension provision (the Riesterrente) in 2001 and the Health Care Fund (Gesundheitsfonds) in 2009, in particular, should be seen as reforms that reconfigure the incentives both to the insured and to providers. Although political compromises watered down these reforms, they introduce changes in pension and health care financing that may serve as institutional templates for future reforms. At the same time, however, key conservative principles concerning benefit entitlement and financing remain largely intact. In both programs, derived rights based on family status remain strong. Similarly, occupational fragmentation continues to characterize the overall 
structure of both systems. Weak attempts to incorporate all income-earners (wage-earners, tenured civil servants, and self-employed professionals) into one universal scheme have been notable failures. Thus, the liberalization of health care and pension provision has not seriously challenged the occupational fragmentation and breadwinner orientation of social policy. In the field of pensions, however, 3 decades of reform have significantly weakened the insurance principle.

Second, 2 decades of reform will produce more inequalities than in the old systems. There is more differentiation in pension levels, and growing numbers of pensioners will receive benefits that are not much higher than the poverty line (Bridgen and Meyer 2014; Hinrichs 2012). Take-up rates for occupational and private pensions are highly stratified by income, as are the value of the tax expenditures and subsidies used to encourage coverage. Similarly, health care reforms will increase individual out-of-pocket expenses, which will hit lower income groups harder. The disparities between private and public insurance have also increased, and the income-levels and conditions of medical practice for various specialties and health sectors are becoming more diversified. In both health and pensions, reforms mean that private actors - banks and insurance companies, on the one hand, and private, for-profit hospital chains, on the otherare gaining both in market share and political influence. Thus, while basic structures and programs remain intact, the social safety net has become substantially thinner.

Third, the article argues that this pattern of institutional change is not new, but is typical of the politics of incrementalism that has characterized the German welfare state since its inception. I emphasize the impact of German political institutions, the structure of electoral competition, and the legacies of conservative social policy to explain this negotiated, incremental pattern of policy development. Bicameralism creates strong incentives for the major parties to compromise on social policy reforms, even when they express different social policy preferences in their electoral strategies. Indeed, the pattern of reform in pensions and health care since the 1990s shows that consensus social policy-making continues to flourish, despite claims to the contrary in the literature (see, for example, Trampusch 2009). Majority governments whose social policy legislation requires the consent of the Bundesrat are usually forced to compromise with the opposition. In making these compromises, the two major 'Volk' parties are torn between two imperatives: electoral competition based on the generosity of social benefits; and the highly-politicized rate of social insurance contributions, a legacy of the systems' dependence on social insurance contribution financing. The parties' partisan visions result in very different proposals to meet these goals; but in the end, the shared conviction that a balance between contribution rates and social spending is a systemic imperative provides the basis for compromise.
These arguments challenge the existing literature in several ways. First, I characterize the trajectory of change not in terms of inevitable responses to negative policy feedbacks (Trampusch 2009; Streeck 2007), but rather as a process of on-going recalibration of highly institutionalized programs underpinned by conservative welfare principles. Reforms in both pensions and health care emphasize costcutting rather than paradigm shift, and the specific mix of instruments employed in this recalibration process is heavily mediated by political compromises. Second, the analysis emphasizes political decision-making rather than industrial relations as the key arena shaping reforms. In doing so, the article emphasizes the political origins of social policies and the ongoing political contestation that shapes social policy development. To be sure, party stances incorporate the views of societal stakeholders, but there is little evidence that changes in the political economy have been the primary driver of welfare state reforms. Nor is there convincing evidence that state intervention was intended to arrest institutional exhaustion caused by labor market practices. Third, the analysis casts doubt on the usefulness of the Varieties of Capitalism (VoC) framework for explaining social policy change. Indeed, there is little evidence that institutional isomorphism and complementarity between systems of social protection and education/industrial relations shaped reform in pensions and health care.

\section{German social politics in the 1990s and 2000s}

The argument developed in the following sections brings electoral and party politics back into the analysis of welfare state change. Ultimately, it is political parties working within the constraints and opportunities provided by the legislative process that determine whether reform will occur or not, and on what terms. To be sure, political actors respond to the appeals and preferences of economic actors in formulating their electoral strategies, but politics is not simply a transmission belt for the preferences of core actors in the political economy (on this point, see Howell 2003), but rather, a highly contingent process. As discussed below, the structure of political institutions in Germany creates incentives for compromise between the two largest parties, the SPD and CDU/CSU. Both parties are generally prowelfare in the sense that they both favor a prominent role for the state in social protection and generous social protection. However, the two parties differ on crucial aspects concerning the design of welfare institutions: on the type of state intervention and on the degree of redistribution. In policy-making, these differences are usually reconciled, and conflicts resolved, because the legislative process rarely provides governments with majorities in both legislative chambers. It is this necessity to compromise, or what Schmidt 


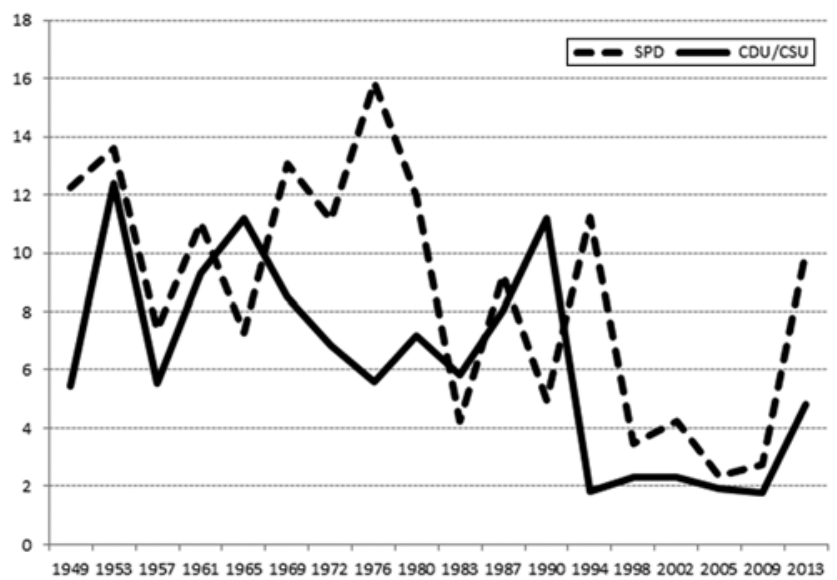

Fig. 1 SPD and CDU/CSU favorable mentions of welfare expansion, election manifestos 1949-2013 (in per cent of quasi-sentences)

(1987) calls the "politics of the middle way", that permeates social policy-making in Germany. The key point here is that conflict and consensus decision-making go hand in hand in countries with the kinds of compromise-forcing institutions that characterize the German political system.

Thus, the argument advanced here is that there is much more continuity in social policy decision-making in Germany than the dominant views in the literature allow. As discussed earlier, much of the literature argues that the social policy reforms of the late 1990s and 2000s constitute a break with the social policy consensus of the post-war period. I argue that this consensus, in the sense of overlapping policy preferences, never really existed; there has always been substantial conflict between the SPD and CDU/ CSU concerning the content and direction of social policy, and that the specific design of German political institutions forced the two major parties to compromise. This social policy-making pattern continues to the present day.

My argument draws on the work of Schmidt (1987), Scharpf (1988), and Katzenstein (1987) in emphasizing the continued importance of institutional constraints on political decision-making in Germany. German political institutions create incentives for compromise, incremental decision-making, and even policy stalemate. Schmidt's contention that Germany is a de facto "grand coalition state" is most apposite here: most major policy reforms require a de facto grand coalition because concurrent majorities in the Bundestag and Bundesrat are fairly uncommon. Thus even when a center-left or center-right government coalition rests on a firm majority in the Bundestag, the fate of its legislative agenda depends on the consent of the Bundesrat. This institutional fragmentation makes it very difficult for parties in government to pursue legislative agendas that depart markedly from the status quo, unless the opposition is on board. Given that most social policy legislation requires Bundesrat

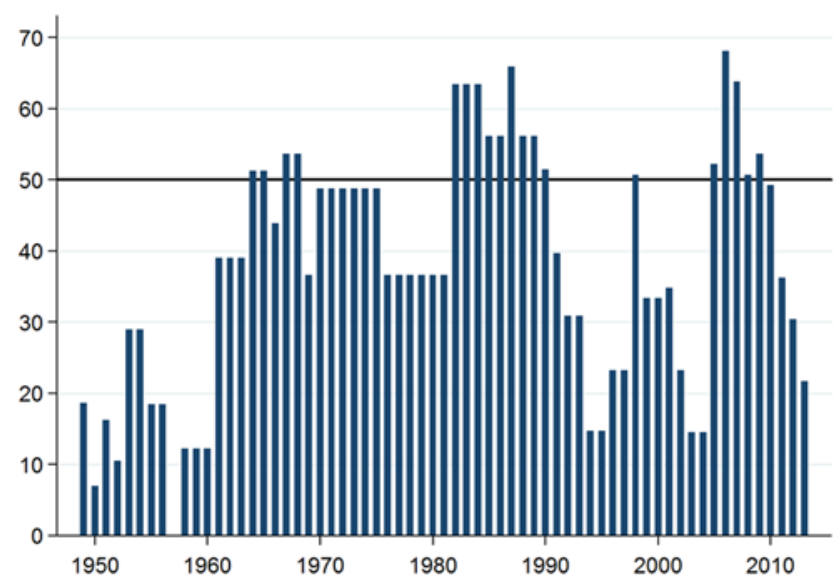

Fig. 2 Government majority stake in the German Bundesrat in \% (last observation per year)

consent, the two major parties must settle their differences before legislative agreement is possible.

Since the 1980s, German politics has been marked by an increase in political competition through the emergence of new parties, as well as an increase in the seats in the Bundesrat as a result of the German unification. Nevertheless, the patterns of consensus democracy have not changed dramatically. Figure 1 uses comparative party manifesto data to show the ideological distance between the two major parties concerning social policy spending over time (Volkens et al. 2015). ${ }^{1}$ The figure does not support the contention that the social policy positions of the CDU/CSU and SPD closely mirrored each other before the 1990s. Indeed, CDU/CSU and SPD positions were closest to each other in the 1953, 1957, and 1961 elections. Starting in 1965, party stances start to diverge substantially, and they only start to move closer in the 1990s. In other words, the contention that consensus characterized social policy-making from the 1960s to the 1990s is not supported by this data (cf. Trampusch 2009; Von Winter 1997).

Data concerning the governmental majorities in the Bundesrat show that parallel majorities in both chambers of parliament have never been the norm. Figure 2 shows the percentage share of seats in the Bundesrat held by government coalition parties between 1949 and January 2014. The horizontal black line indicates the $50 \%$ majority threshold. There were concurrent government party majorities in the Bundesrat in 19 of the 64 years since 1949. Thus, even when a center-left or center-right government coalition rested on a firm majority in the Bundestag, the fate of many elements of the government's legislative agenda usually depended on

\footnotetext{
${ }^{1}$ For example, in $1976,16 \%$ of the quasi-sentences in the SPD manifesto mentioned welfare state expansion favorably, compared to $5.5 \%$ in the $\mathrm{CDU} / \mathrm{CSU}$ manifesto.
} 
the consent of the Bundesrat. ${ }^{2}$ Furthermore, even in periods when double majorities allowed the governmental parties to impose reform (as in the Kohl era), they were vulnerable to reversal if power changed hands at the next election, as I discuss at more length below. The result was usually lowest common denominator policies that could attract support from both large 'catch-all' parties.

\section{Two cases of social policy making: pensions and health care}

The next two sections make two claims concerning the direction of reforms in both pensions and health care since 1990. First, the pattern of consensual policy-making that characterized the post-war period to 1990 has not been replaced by conflictual decision-making. Indeed, the "politics of the middle way" continues to be the most accurate descriptor of social policy-making during the post-1990s period, with party differences emphasized in elections, and middle-ofthe-road compromises reached during policy negotiations in the legislative process. Second, policy change in both pensions and health care display very strong continuities with the past. To be sure, both systems have undergone important institutional changes, but the basic structure of both systems remains stable in terms of benefit entitlement (occupational fragmentation), the promotion of marriage and child-bearing, and contribution financing. The most far-reaching changes have concerned administration and financing. Organized interests no longer dominate administration as they did in the past, and individuals and households bear a significantly larger burden of the costs of both systems. A wholesale paradigm shift has not taken place in either system, but the reforms adopted since 1990 have the potential to be transformative in the long run because they may be used to slowly change the logic underlying both systems.

\subsection{Pension reform}

The statutory pension system is the most important part of the social insurance system and is the largest social program in terms of spending. Retirement provision is organized according to Bismarckian principles: wage earners participate in the statutory pension scheme (Gesetzliche Rentenversicherung, $G R V$ ), tenured civil servants have their own, tax-financed schemes, and self-employed professionals have their own schemes. There are also smaller public schemes for farmers and miners. A central goal of the system is to provide benefits that promote status maintenance: retirement income should mirror the pattern of earnings

\footnotetext{
${ }^{2}$ Legislation that affects the activities of the federal states (Länder)
} requires the consent of the Bundesrat. while in employment. Prior to 2001, the standard pension for an average earner was $70 \%$ of average net wages. Payroll contributions evenly divided between employers and employees (up to a ceiling equal to twice average earnings) financed benefits until recent reforms, with the government providing a subsidy (Bundeszuschuss) to help cover costs and to finance pension accrual for which no contribution was paid (for example, for child-rearing). The basis for pension entitlement was expanded starting in the 1960s to include periods spent in education, unemployment, and child-rearing (Schulze and Jochem 2007; Hinrichs 2012).

The structure of the system means that public benefits dominate, and private and occupational pensions are relatively underdeveloped (until recent reforms; see below). In 2011 , the statutory pension accounted for $75 \%$ of all pension payments to those 65 or older. If we include all income, for example from capital or real estate, the picture is slightly different. In this case the statutory pension accounts for $64 \%$ of all gross income for those 65 and older. Pensioners in the former West Germany receive more income from other sources (Bundesministerium für Arbeit und Soziales 2013, p. 96). Figure 3 shows the sources of gross income for persons aged 65 and older.

Men's pensions are substantially higher than women's. Current pensioners entered employment starting in the 1940s, when traditional gender roles were more common. The average man's net pension was $€ 1695$ in 2011, while the average woman's net pension was $€ 1027$ (figures are for monthly pension amounts). The numbers are quite different if we consider marital status. Married women receive, on average, much lower net pensions, at $€ 686$. Married men receive an average net pension of $€ 1746$ (Bundesministerium für Arbeit und Soziales 2013, p. 101). These substantial differences in men's and women's pensions are not surprising given the strong breadwinner orientation of the labor market and welfare state until recently. Tax policy, wage policy and the underdevelopment of social services created very strong incentives for a traditional gender division of labor (Daly 2000; Anderson and Meyer 2006; Meyer 2013), and women's labor market participation remained low (in European perspective) until the 1980s.

After a period of expansion, policy development since the 1980s has been driven by two factors. First, policymakers have grappled with the consequences of rising unemployment and the rising share of pensioners relative to workers, both of which put pressure on contribution rates. German unification exacerbated this problem. Second, policymakers have made several attempts to adapt pension entitlement to reward not just labor market participation, but also childrearing. Cost-cutting reforms have, however, dominated (Schulze and Jochem 2007; Hinrichs 2012).

The social insurance-based structure of the statutory pension has been the target of reform since the 1960s. If social 
Fig. 3 Income sources of those 65 and older, 2011

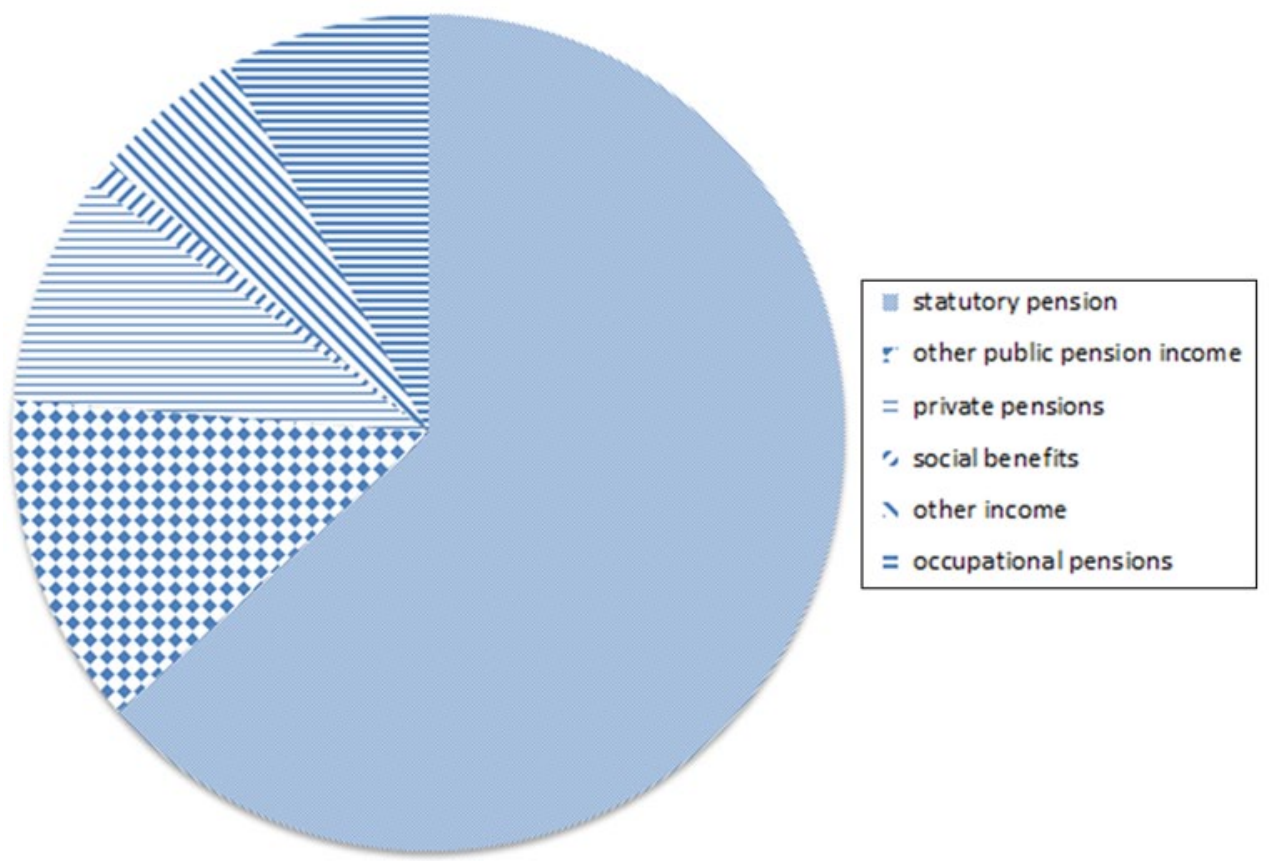

Fig. 4 Statutory pension contribution rate, 1970-2014 (\% of qualifying wages). (Source: Gesundheitsberichterstattung des Bundes)

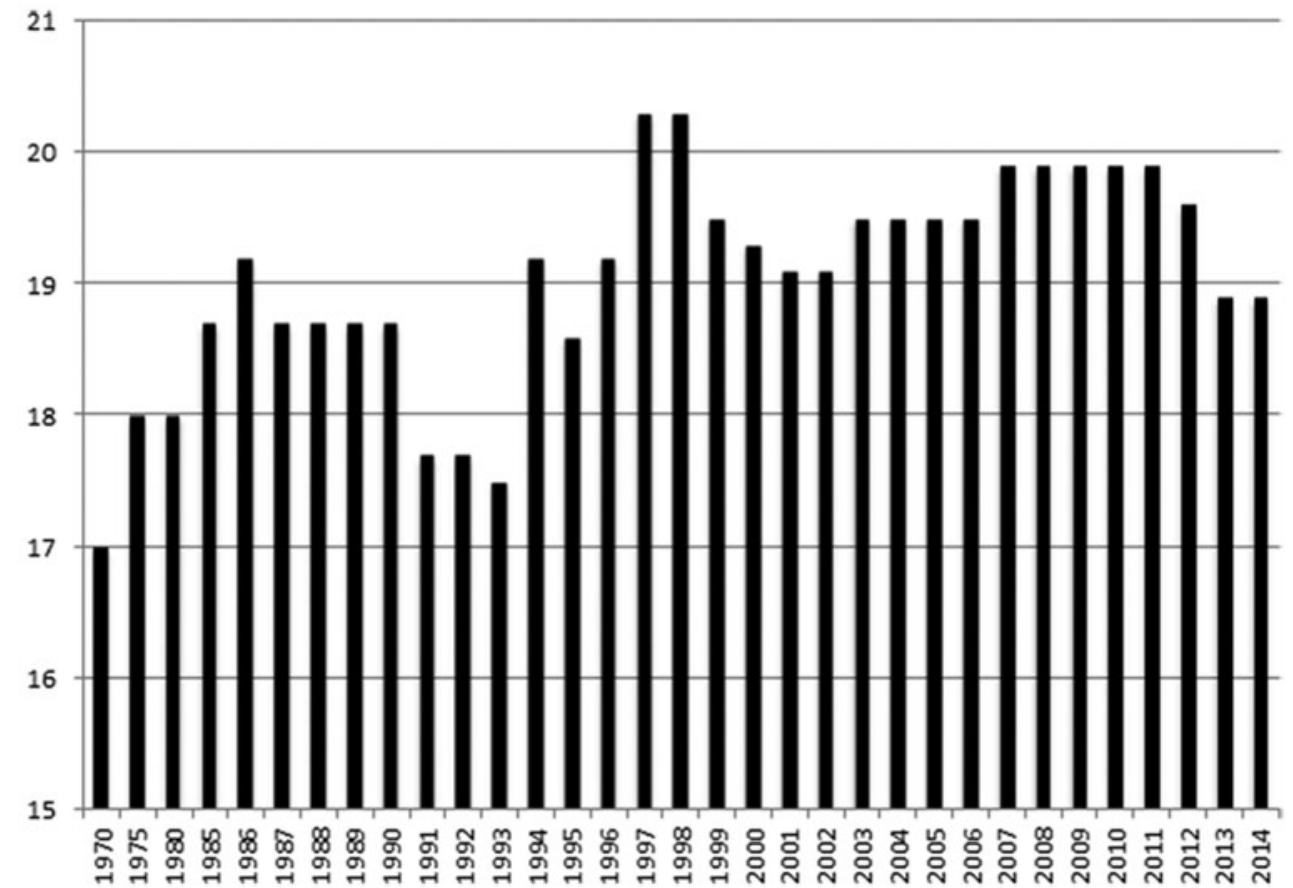

insurance contributions finance defined benefits, the locus of adjustment is always on the contribution side, rather than the benefit side. Starting in the late 1960s, policy-makers began raising contributions to finance anticipated increases in the number of pensioners relative to workers (Hockerts 2011). The unemployment crises of the 1970s, 1980s, and 1990s led to more contribution hikes (Fig. 4), as did German unification, because the social insurance system was used to absorb much of the cost of unification (Manow and Seils 2000). Rising unemployment meant that the revenue base (pension-qualifying payroll) did not increase in line with pension costs, and this pushed up non-wage labor costs as well as state expenditures (Fig. 4). Policy-makers have responded to growing pension costs by increasing the federal subsidy (Bundeszuschuss) to the statutory pension system. As Fig. 5, shows, the federal subsidy remained fairly stable between 1979 and the mid-1990s, financing 18-22\% of expenditure. Starting in 1998, however, reforms have expanded the overall size of the federal subsidy through the creation of special subsidies financed by ear-marked rev- 
Fig. 5 Size of federal subsidies to statutory pension, as per cent of total pension costs, 1960-2012. (Source: Gesundheitsberichterstattung des Bundes)

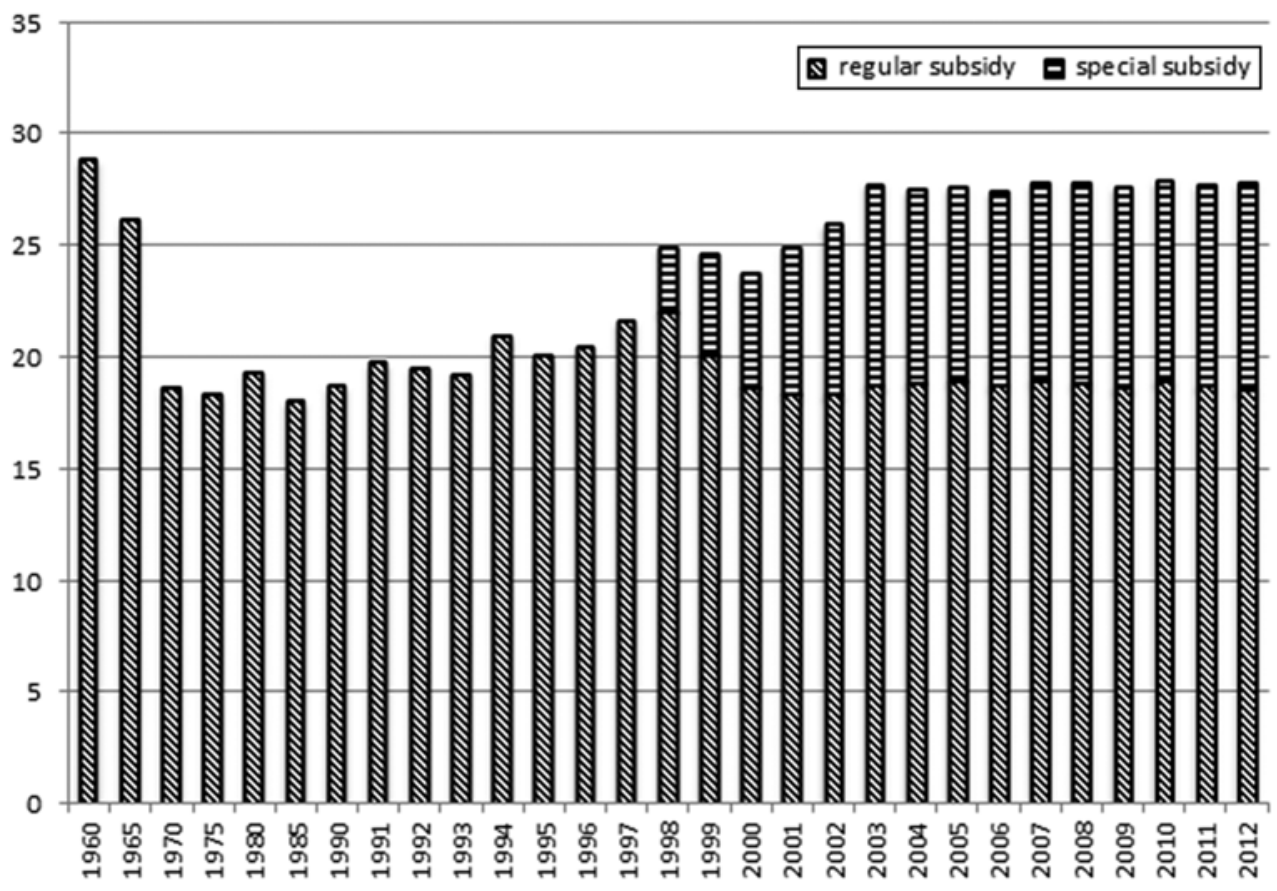

enue sources, such as a proportion of VAT and a new eco-tax (Ökosteuer) revenues. Thus, even if political actors agreed on the basic features of the system, high contribution rates and growing state pension costs created strong incentives for cost-cutting and measures to strengthen financing.

In addition to these financial pressures, the pension system came under pressure for its one-sided focus on employment as the basis for entitlement. In particular, rulings by the Constitutional Court since the mid-1980s required several governments to introduce pension credits for child rearing (Anderson and Meyer 2006). As discussed below, the reforms of the 2000 s and 2010 s strengthen this trend.

The content of pension reform since 1989 emphasizes cost-cutting in order to adjust the system to demographic trends. Reforms rely on the familiar tools of pension retrenchment: benefit cuts, raising the retirement age, and expanding non-state provision. In addition, the generosity of survivors pensions has been reduced and pension entitlement for child-rearing has been improved. The 1989 pension reform passed under the CDU/CSU-FDP government led by Helmut Kohl introduced modest benefit cuts, limits on early retirement, and a higher retirement age for women, the unemployed and disabled. At the same time, pension rights for child-rearing were increased from 1 to 3 years, and the size of the federal subsidy was increased (Schulze and Jochem 2007; Schludi 2005).

An important aspect of the 1989 reform is that it was adopted with the support of the opposition SPD and by a unanimous Bundesrat where the government parties had a majority. The legislation reflects the nature of this compromise: the CDU/CSU and FDP gained support for impor- tant cost-cutting measures while the SPD won concessions in terms of the retirement age and the size of the federal subsidy. Most analysts interpret this pattern of support as evidence for the consensus-oriented nature of pension policy-making prior to the 1990s (see, for example, Trampusch 2009; Nullmeier and Rüb 1993). The analysis presented here, in contrast, offers an equally plausible explanation for cross-party cooperation: the SPD faced strong, institutionally-induced incentives to cooperate with the governing coalition to prevent pension cuts from dominating the election scheduled for 1990. For the SPD, cooperation created an opportunity to influence aspects of the legislation important to party interests, particularly increasing the federal subsidy and limiting cuts on early retirement (Schludi 2005). The CDU/CSU also stood to gain from SPD cooperation because voters would not be able to trace pension cuts directly back to the party; instead, the CDU/CSU would share the blame for cuts with the SPD (on blame avoidance, see Pierson 1994).

The costs of German unification and poor employment performance were the backdrop to the Kohl government's other important pension reform, the Pension Reform Act 1999 (adopted in 1997). The reform included modest cuts in disability pensions, a demographic factor linking benefits to changes in life expectancy, another increase in the federal subsidy, and improvement in the value of pension credits for child-rearing. Unlike the 1989 pension compromise, however, the CDU/CSU-FDP government now faced a Bundesrat dominated by the SPD. To head off a Bundesrat veto, the government divided the legislation into two parts, one that did not need the consent of the Bundesrat, and one that 
did. The non-financial provisions of the reform were thus included in the Pension Reform Act 1999, which the Bundestag adopted in October 1997. The Bundesrat used its right to object to the legislation, but the Bundestag was able to overrule this by a simple majority. The financial heart of the reform, the increase in the federal subsidy, was then introduced as separate legislation requiring the approval of both chambers. After a complicated negotiation process in which the SPD in the Bundesrat agreed to support the legislation if it included an increase in the federal subsidy (financed by an increase in VAT) and improved pension coverage for the marginally employed (which ultimately failed), both chambers adopted the legislation. (see Schulze and Jochem 2007 and Schludi 2005 for detailed analyses).

The change of government in 1998 now gave the SPDGreen government the legislative initiative under very favorable conditions: the governing parties enjoyed majorities in both the Bundestag and Bundesrat. During the election campaign, Red-Green promised to reverse some of the pension cuts legislated by the previous government, advancing their own, alternative pension agenda. The Red-Green government quickly adopted legislation in December 1998 that reversed the demographic factor and some disability pension cuts that were part of the 1997 reform. The legislation, the Pension Correction Act, sailed through the SPDdominated Bundesrat. The reform also included measures to stabilize the pension contribution rate and increase the federal subsidy.

The Red-Green government's more ambitious pension reform plans were announced in 1999: modest long-term pension benefit cuts and expanded private provision. The steady increase in the pension contribution (breaching the informal limit of $20 \%$ ) was a highly-visible threat to employment that could not be ignored, and the reform was intended to correct this problem. Consequently, the SPD drew on Social Minister Riester's proposal for a compulsory private pension, for which contributions would be gradually increased to $4 \%$ of wages. As a result of the political bargaining over the original Riester proposal-which was not acceptable to either coalition partners, the opposition, and even large parts of the SPD - a voluntary, tax-subsidized private pension program was introduced, at the same time that substantial savings were achieved by freezing pension indexation for 2 years (see Anderson and Meyer 2003; Schulze and Jochem 2007 for details of the reform process).

A change in the Bundesrat majority made the Red-Green pension reform project much more difficult. In October 1999 SPD-led states in the Bundesrat controlled 26 seats, CDU/CSU-led states 32 seats, while states governed by grand coalitions controlled 11 votes. With 35 votes needed for a majority, Red-Green would have to compromise on the parts of the reform requiring Bundesrat consent. In preparing the legislation, Red-Green invited the opposition to cooperate, and when this failed, the government acquiesced to several CDU/CSU demands in order to secure the Bundesrat's consent. Concessions included linking subsidies for private insurance to the number of children in a household, increasing the size of subsidies for private provision, and locating employment related to the new private pensions in the states of Berlin and Brandenburg (Anderson and Meyer 2003; Zolnhöfer 2008).

Subsequent reforms build on this mix of cost-cutting, incentives for private provision and expansion of coverage for child-rearing. The Red-Green government adopted an incremental reform in 2004 (The Rürup Reform) that includes several modest benefit cuts (less favorable indexation, introduction of a sustainability factor to limit spending growth and a 1-year pension freeze). To soften these cuts, the reform also introduced a maximum benefit cut (benefits may not fall below $46 \%$ of previous average wages for a standard pensioner). The legislation did not require the consent of the Bundesrat; however, the Bundesrat used its right to object to the legislation. The Bundestag overrode this objection with the required simple majority. Red-Green was also able to attract opposition support for another 2004 reform, the Law on Income in Old Age, that introduced modest adjustments to the new private pension products and implemented a technical change in the taxation of public pensions. A decision by the Constitutional Court required changes to pension taxation (so that the tenured civil servant pensions were taxed under the same rules as public pensions). The legislation required the consent of the Bundesrat which was dominated by the opposition. The federal state Bavaria tried to mobilize opposition to the legislation in the Bundesrat, but there were enough votes in favor by CDU governments to secure passage, because of Red-Green concessions concerning the taxation of insurance products (Handelsblatt, 11 June 2004).

The final important reform of the 2000s was the introduction of a higher retirement age in legislation passed in 2007, with effect in 2012. The law raises the statutory retirement age from 65 to 67 between 2012 and 2029. The legislation did not require Bundesrat consent, and it passed easily.

How do these reforms change the basic structure and goals of the pension system? As Fig. 5 shows, the state's share of pension financing has increased substantially. This is the result of measures introduced to relieve upward pressure on payroll contributions and to finance periods of insurance that are not financed by payroll contributions. A second substantial change is the significant reduction in future benefits. Between 1990 and 2014, the pension for a worker with 45 years of employment at average wages has decreased from 55.1 to $48 \%$ of average earnings. By 2028 , the replacement rate is forecast to be $44.4 \%$. Indeed, recent pension analyses from the government openly admit that the public pension will not be high enough to maintain 
Table 1 The development of combined public/private pension replacement rates for an average earner. (Source: Bundesministerium für Arbeit und Soziales 2013, p. 176)

\begin{tabular}{|c|c|c|c|c|c|}
\hline \multirow[t]{2}{*}{ Year of retirement } & \multirow[t]{2}{*}{ Gross replacement rate $(\%)$} & \multicolumn{3}{|c|}{ Consisting of } & \multirow{2}{*}{$\begin{array}{l}\text { Net combined replacement } \\
\text { rate }(\%)\end{array}$} \\
\hline & & $\overline{\text { GRV }}$ & Riester pension (\%) & Private pension $(\%)$ & \\
\hline 2012 & 47.4 & 45.5 & 1.7 & 0.2 & 70.7 \\
\hline 2015 & 47.4 & 44.6 & 2.4 & 0.4 & 70.1 \\
\hline 2020 & 48.5 & 44.0 & 3.7 & 0.9 & 70.9 \\
\hline 2025 & 48.8 & 42.3 & 4.9 & 1.6 & 71.8 \\
\hline 2030 & 49.3 & 40.6 & 6.2 & 2.5 & 72.8 \\
\hline
\end{tabular}

a pensioner's previous standard of living (Bundesministerium für Arbeit und Soziales 2013, p. 12). An explicit goal of reforms since 2001 has been the voluntary expansion of private and occupational pensions to compensate for cuts in the statutory pension. Since the 2001 pension reform, occupational pensions have increased significantly. In 2001 there were 14.6 million active occupational pension contracts, and this had increased to 19.6 million in 2011 (an increase of $34 \%$ ) (Bundesministerium für Arbeit und Soziales 2013, p. 135). The 2001 reform also included provisions allowing workers to use request tax-favored salary sacrifice (Entgeltumwandlung); salary sacrifice is the most important driver of the increase in occupational pension provision in the last 10 years (Bundesministerium für Arbeit und Soziales 2013, p. 137). In addition, individuals may buy tax-preferred individual contracts (the Riester pension). At the end of June 2012, there were 15.6 million individual Riester contracts. In 2012 , about $70 \%$ of those covered by the statutory system had additional pension coverage.

According to simulations from the Ministry of Social Affairs and Employment, an average earner with an uninterrupted employment biography will continue to receive a net pension from all sources (statutory pension, Riester pension, private pension) equal to at least $70 \%$ of net average earnings in 2012. As Table 1 shows, the net pension income from all sources remains at least $70 \%$ provided that the individual saves the maximum amounts in the new Riester pension plans.

Many, if not most, wage earners do not have a complete, full time employment biography with average earnings. Wage earners with low incomes save too little for retirement: $42 \%$ of those earning less than $€ 1500$ gross per month do not have an occupational pension or a Riester contract. Two thirds of those without supplementary coverage are women (Bundesministerium für Arbeit und Soziales 2013, p. 9). Moreover, workers with average or above average earnings who experience spells of unemployment will receive a combined net pension that is 5-6 percentage points lower than the pension received by someone with an on interrupted employment biography (Bundesministerium für Arbeit und Soziales 2013, p. 177).

Despite cuts in overall pension provision, recent reforms have also attempted to address some of the lingering inequal- ities in the system. For example, the new Rürup-Rente is a tax-preferred basic pension introduced at the beginning of 2005 as part of the Law on Income in Old Age. This pension is modeled on the statutory pension and is aimed at the selfemployed. At the end of June 2012 there were 1.6 million Rürup pension contracts (Bundesministerium für Arbeit und Soziales 2013, p. 152).

The grand coalition government in power since 2013 has responded to concerns about growing inequalities at the lower end of the wage scale by introducing a pension for low income earners with long employment histories (Lebensleistungsrente): those who have paid at least 45 years into the statutory pension system can now retire at age 63 . This is a partial reversal of recent reforms that raise the retirement age. Additionally, the government's 2014 pension package improves pension entitlement for parents of children born before 1992. The tenor of these reforms is to increase the value of child years for parents and years for other kinds of care and to improve the pension rights of those on a low income. Neither reform required the consent of the Bundesrat, and they both passed easily.

It is also worth noting what reforms have not changed in the German pension system. The SPD has made weak attempts to reduce occupational fragmentation by including tenured civil servants in the statutory pension, but these efforts came to nothing. This means that occupational fragmentation remains a core feature of the German system. More interesting for the present purposes is the role of conservative principles in the ongoing reform of the statutory pension and in the design of the new Riester pension. Reforms since 1986 have expanded pension rights for child rearing. This is largely consistent with the conservative norms underpinning the German welfare states, because pension accrual for child rearing can discourage female labor market participation and encourage women to continue care work in the home. Moreover, tax preferences and government subsidies for Riester pension contracts are higher for those with a spouse or children than they are for unmarried persons and/or those without children.

Table 2 summarizes the reforms discussed in the previous section. The 1990s and 2000s have been marked by reforms that introduce substantial long-term reductions in benefit levels, encourage private provision to compensate 
Table 2 Pension reforms since 1989. (Source: Schulze and Jochem (2007); www.bmas.de)

\begin{tabular}{|c|c|c|c|c|c|c|}
\hline $\begin{array}{l}\text { Year } \\
\text { en- } \\
\text { acted }\end{array}$ & Name & $\begin{array}{l}\text { Parties } \\
\text { in gov- } \\
\text { ern- } \\
\text { ment }\end{array}$ & $\begin{array}{l}\text { Govern- } \\
\text { ment ma- } \\
\text { jority in } \\
\text { Bundesrat? }\end{array}$ & $\begin{array}{l}\text { Consent } \\
\text { Bundes- } \\
\text { rat } \\
\text { required? }\end{array}$ & $\begin{array}{l}\text { Both SPD } \\
\text { and CDU/ } \\
\text { CSU } \\
\text { support } \\
\text { reform? }\end{array}$ & Reform content \\
\hline 1989 & $\begin{array}{l}\text { Pension Reform Act } 1992 \\
\text { (Rentenreform 1992) }\end{array}$ & $\begin{array}{l}\mathrm{CDU} / \\
\mathrm{CSU} \\
\& \mathrm{FDP}\end{array}$ & Yes & Yes & $\begin{array}{l}\text { SPD } \\
\text { involved } \\
\text { in for- } \\
\text { mulating } \\
\text { legislation }\end{array}$ & $\begin{array}{l}\text { Shift from gross to net wage indexation } \\
\text { Higher retirement age for women, unemployed, } \\
\text { disabled } \\
\text { Introduction of deductions for early retirement } \\
\text { Increase in child rearing credits from } 1 \text { to } 3 \text { years }\end{array}$ \\
\hline 1997 & $\begin{array}{l}\text { Pension Reform Act } 1999 \\
\text { (Rentenreform 1999) }\end{array}$ & $\begin{array}{l}\mathrm{CDU} / \\
\mathrm{CSU} \\
\& \mathrm{FDP}\end{array}$ & No & No & No & $\begin{array}{l}\text { Introduction of demographic factor } \\
\text { Increase in child credits from } 75 \text { to } 100 \% \text { of aver- } \\
\text { age wage (max three credits per child) } \\
\text { Modest cuts in disability benefits }\end{array}$ \\
\hline 1997 & $\begin{array}{l}\text { Law for financing an addi- } \\
\text { tional federal subsidy to the } \\
\text { statutory pension system } \\
\text { (Gesetz zur Finanzier- } \\
\text { ung eines zusätzlichen } \\
\text { Bundeszuschusses zur geset- } \\
\text { zlichen Rentenversicherung) }\end{array}$ & $\begin{array}{l}\mathrm{CDU} / \\
\mathrm{CSU} \\
\& \mathrm{FDP}\end{array}$ & No & Yes & $\begin{array}{l}\text { Some } \\
\text { SPD } \\
\text { states in } \\
\text { Bundesrat } \\
\text { support } \\
\text { legislation }\end{array}$ & $\begin{array}{l}\text { Increase in federal subsidy to pension system } \\
\text { through } 1 \% \text { point increase in VAT }\end{array}$ \\
\hline 1998 & $\begin{array}{l}\text { Pension Correction Act } \\
\text { (Gesetz zu Korrekturen } \\
\text { in der Sozialversicherung } \\
\text { und zur Sicherung der } \\
\text { Arbeitnehmerrechte) }\end{array}$ & $\begin{array}{l}\text { SPD \& } \\
\text { Greens }\end{array}$ & Yes & Yes & No & $\begin{array}{l}\text { Cancellation of the demographic factor } \\
\text { Cancellation of cuts in disability pensions }\end{array}$ \\
\hline 2001 & $\begin{array}{l}\text { Altersvermögensgesetz } \\
(A V m G)\end{array}$ & $\begin{array}{l}\text { SPD \& } \\
\text { Greens }\end{array}$ & No & Yes & $\begin{array}{l}\text { Some } \\
\text { CDU } \\
\text { states in } \\
\text { Bundesrat } \\
\text { support } \\
\text { legislation }\end{array}$ & $\begin{array}{l}\text { Introduction of voluntary, subsidized private } \\
\text { pensions }\end{array}$ \\
\hline 2001 & $\begin{array}{l}\text { Altersvermögensergänzungs- } \\
\text { gesetz }(A V m E G)\end{array}$ & $\begin{array}{l}\text { SPD \& } \\
\text { Greens }\end{array}$ & No & No & No & $\begin{array}{l}\text { Net replacement rate for statutory pensions cut } \\
\text { from } 70 \text { to } 64 \% \text { of average wages } \\
\text { Max. contribution rate } 20 \% \text { until } 2020 \\
\text { Introduction of means-tested minimum pension } \\
\text { Reduction of survivor's pension from } 60 \text { to } 55 \% \text { of } \\
\text { deceased's benefits }\end{array}$ \\
\hline 2004 & $\begin{array}{l}\text { Rürup Reform } \\
\text { RV-Nachhaltigheitsgesetz }\end{array}$ & $\begin{array}{l}\text { SPD \& } \\
\text { Greens }\end{array}$ & No & No & No & $\begin{array}{l}\text { Introduction of sustainability factor } \\
\text { Max. benefit cut not less than } 46 \% \text { of average wage } \\
\text { Less favorable indexation } \\
\text { Suspension of pension adjustment for } 2004 \\
\text { Abolition of credit points for higher education } \\
\text { Retirement age for unemployed and partial pension } \\
\text { raised from } 60 \text { to } 63\end{array}$ \\
\hline 2004 & $\begin{array}{l}\text { Law on income in old age } \\
\text { Alterseinkünftegesetz }\end{array}$ & $\begin{array}{l}\text { SPD \& } \\
\text { Greens }\end{array}$ & No & Yes & $\begin{array}{l}\text { Some } \\
\text { CDU } \\
\text { states in } \\
\text { Bundesrat } \\
\text { support } \\
\text { legislation }\end{array}$ & $\begin{array}{l}\text { Switch from taxation of pension contributions to } \\
\text { taxation of pension benefits } \\
\text { Introduction of unisex benefits in Riester Rente } \\
\text { Streamlined rules for Riester Rente products }\end{array}$ \\
\hline 2007 & $\begin{array}{l}\text { Gesetz zur Anpassung der } \\
\text { Regelaltersgrenze an die } \\
\text { demografische } \\
\text { Entwicklung und zur } \\
\text { Stärkung der Finanzierungs- } \\
\text { grundlagen der gesetzlichen } \\
\text { Rentenversicherung ( } R V \text { - } \\
\text { Altersgrenzenanpassungsge- } \\
\text { setz) }\end{array}$ & $\begin{array}{l}\text { SPD \& } \\
\text { CDU/ } \\
\text { CSU }\end{array}$ & Yes & No & Yes & $\begin{array}{l}\text { Gradual increase in "standard" retirement age from } \\
65 \text { to } 67 \text {, starting in } 2012\end{array}$ \\
\hline
\end{tabular}


Table 2 (continued)

\begin{tabular}{lllllll}
\hline $\begin{array}{l}\text { Year } \\
\text { en- } \\
\text { acted }\end{array}$ & Name & $\begin{array}{l}\text { Parties } \\
\text { in gov- } \\
\text { ern- } \\
\text { ment }\end{array}$ & $\begin{array}{l}\text { Govern- } \\
\text { ment ma- } \\
\text { jority in } \\
\text { Bundesrat? }\end{array}$ & $\begin{array}{l}\text { Consent } \\
\text { Bundes- } \\
\text { rat } \\
\text { required? }\end{array}$ & $\begin{array}{l}\text { Both SPD } \\
\text { and CDU/ }\end{array}$ & $\begin{array}{l}\text { RSU } \\
\text { support } \\
\text { reform? }\end{array}$ \\
\hline 2014 & $\begin{array}{l}\text { Pension package } \\
\text { Pensions for those with long content } \\
\text { work histories } \\
\text { (Lebensleistungsrente) } \\
\begin{array}{l}\text { Mothers pension } \\
\text { (Mütterrente) }\end{array}\end{array}$ & $\begin{array}{l}\text { CDU/ } \\
\text { CSU }\end{array}$ & Yes & No & Yes & $\begin{array}{l}\text { Full pension at age 63 for those with 45 years of } \\
\text { earnings } \\
\text { Mothers of children born before 1992 receive child- } \\
\text { rearing credits } \\
\text { Modest increase in disability pension }\end{array}$ \\
\hline
\end{tabular}

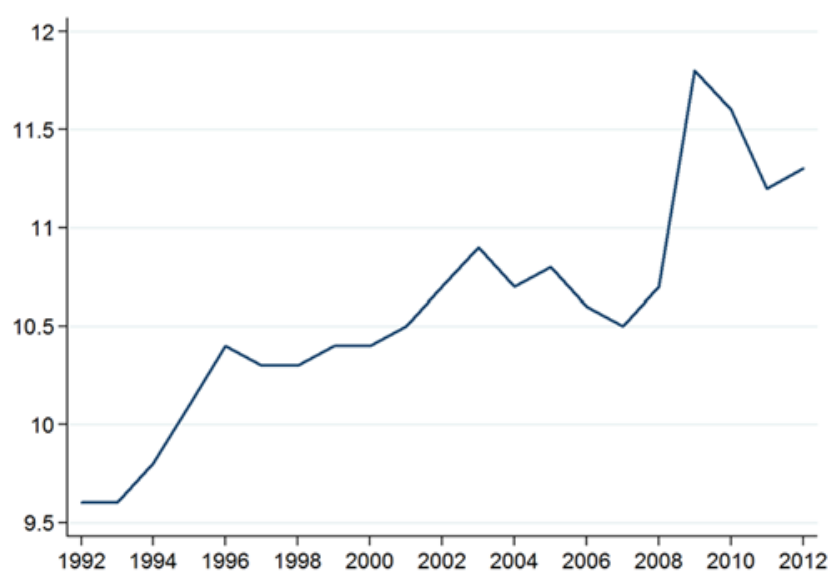

Fig. 6 Total expenditure on health care in \% GDP. (Source: Gesundheitsberichterstattung des Bundes)

for these cuts, and stabilize contribution rates. The reforms since 2010, in contrast, offer modest corrections to earlier cuts by increasing the value of child years for some cohorts and re-introducing early retirement for those with long employment histories.

Grand coalition bargaining in the context of federal decision-making institutions has had a decisive influence on this incremental pattern of reform. The SPD and CDU/CSU cooperated on the passage of 6 of the 10 reforms analyzed here (Table 2), either as formal coalition partners (2007, 2014), informal partners (1989), or after negotiations in the Bundesrat $(1997,2001,2004)$.

\subsection{Health care reform}

The German health care system is also organized according to Bismarckian principles: workers in dependent employment are required to participate in the national Statutory Health Insurance (SHI) system. Workers with an income above the statutory insurance ceiling (about two times average wages) may stay in the statutory system or take out private health insurance. Tenured civil servants have their own schemes, supplemented by private insurance. Statutory sickness funds (Krankenkassen) cover about $88 \%$ of the
German population and finance about $57 \%$ of health care costs (figures for 2006; Müller and Böhm 2009, p. 38). Like pensions, the institutional structure of the health care system has remained fairly stable since the end of the nineteenth century (Stone 1980; Alber 1992; Immergut 2009). Statutory benefits are financed by payroll contributions divided evenly between workers and employers (up to the contribution ceiling). Dependent spouses and children are included in the insurance coverage of the wage earner in dependent employment. Until recently, corporatist health care actors were responsible for central features of health care decisionmaking and implementations. The sickness funds set their own contribution rates, and the powerful Associations of SHI Physicians (Kassenärztliche Vereinigungen) negotiated payments with the sickness funds, as did hospitals.

Like pensions, the health care system has been the object of reform efforts since the 1980s, largely because of rising costs and the resulting upward pressure on contribution rates. Between 1992 and 2012, total health care spending increased from about $9.5 \%$ of GDP to $11.3 \%$ of GDP (with notable decreases between 2003 and 2007 and 2009 and 2011; see Fig. 6). The structure of health care financing created problems similar to those in pensions: social insurance contributions levied on payroll meant that contribution increases were implicated in debates about rising non-wage labor costs. It was precisely this feature of the health care system - which reached dramatic proportions after German unification - that provided the impetus for reform. The rising cost of health care could not be externalized onto consumers or taxpayers, but rather, would have to be borne by social insurance contributions. At the same time, health care advocates argued that in an aging society, a proportion of the wage bill is not an adequate guide for allocating resources into the health care area.

Health insurance reforms have not attempted to restructure the basic features of the health care system; instead, they have tried to promote efficiency and cost savings by modifying the incentives and constraints faced by actors in the health care system. Governance structures, especially the complicated administrative arrangements that determine the fees paid by the sickness funds to doctors, hospitals and 


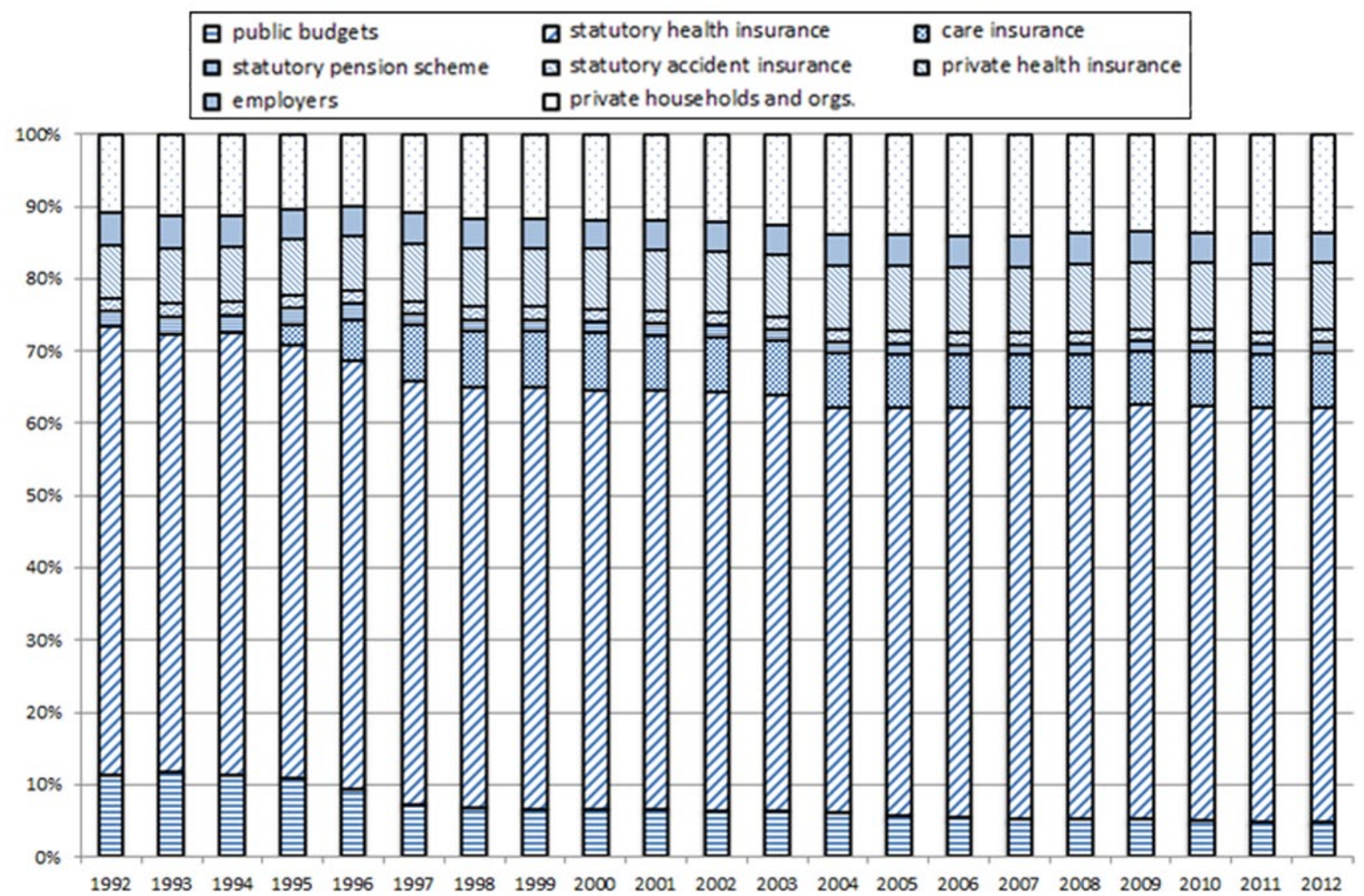

Fig. 7 Share of total health care financing, by type of payer. As \% of total health care spending, 1992-2012. (Source: Gesundheitsberichtserstattung des Bundes)

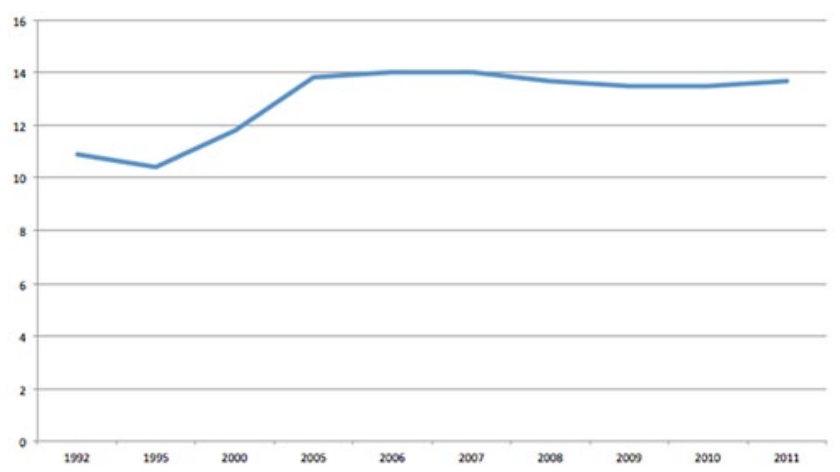

Fig. 8 Share of health care costs paid by private households and nonprofit organization, in \% of total spending. (Source: Gesundheitsberichterstattung des Bundes)

other health care providers have been a particular target of reform. Nearly all of the reforms adopted since 1988 introduce some form of cost-cutting: the introduction or increase of co-payments for medication, medical supplies, office visits and hospital stays. In addition, services and pharmaceuticals - notably dental fixtures - have been removed from the catalogue of treatments covered by social insurance. This has resulted in a significant shift in the burden of paying for health care, from the sickness funds to households (see below, Figs. 7 and 8). Reforms have also aimed to reduce costs and increase efficiency by stimulating competition. For example, wage earners have had free choice of sickness fund since 1997. Similarly, case-based payments for hospitals (Diagnosis-Related Groups, DRGs), and the weakening of the institutional separation between ambulatory and stationary medical care aim to improve health care delivery by changing the incentives to providers. However, despite the emphasis on cost-cutting of the CDU/CSU-FDP government (1983-1998), DRG payments have increased the incentives to hospitals to provide services, and hence to an increase in hospital costs. Furthermore, favorable negotiations with medical organizations under both the Red-Green (1998-2005) and Grand Coalition (2005-2009; 2013-present) governments have also increased health care costs.

The 1988 Health Reform Law was one of the first to address the growth of health care expenditure and its impact on non-wage labor costs. Most health care reform legislation was subject to Bundesrat consent at the time, but the CDU/CSU-FDP government enjoyed concurrent majorities in the Bundestag and Bundesrat, which would facilitate passage. Nevertheless, the SPD and CDU/CSU tried to 
negotiate a compromise reform in the pre-legislative phase, but this came to nothing because of strong disagreements in reform priorities. The CDU/CSU (and its coalition partner, the FDP) favored marginal changes that maintained governance structures and spread the costs of reform across all stakeholders (providers, patients, contribution-payers). The SPD advocated reforms of health care governance and emphasized individual health rather than provider payments (Perschke-Hartmann 1994). The 1988 legislation introduced very modest changes: more and higher co-payments for prescription drugs and a reduction of the number of prescription drugs eligible for reimbursement. The opposition in the Bundestag (SPD, Greens, and PDS) voted against the legislation, but it passed easily in both chambers because of concurrent government majorities.

The 1992 Health Structure Act (Gesundheitsstrukturgesetz), legislated by an informal grand coalition (the opposition SPD participated in formulating the legislation), changed the parameters governing decision-making about health care by introducing top-down steering instruments such as limits on the numbers of physicians allowed to participated in statutory health care provision and budget caps. The reform also allowed free choice of sickness insurance fund, thereby weakening one of the sickness funds' sources of organization strength. With the SPD on board at an early stage, passage in the SPD dominated Bundesrat was assured. The 1996 Law to Decrease Contributions built on this orientation by proposing additional modest reductions in reimbursements for dental care, higher co-payments for prescription drugs, and other incremental reductions. The legislation was based on intensive negotiations with the SPD as part of the bipartisan Alliance for Jobs; controlling health care costs was seen as a way to reduce non-wage labor costs and boost employment. The SPD was divided about whether to accept deteriorations, but opted to support the legislation in order to reduce the cost of labor (Jochem 2009).

The CDU/CSU-FDP coalition continued its reform efforts with the 1997 Statutory Health Care Reorganization Act, which introduced modest competition by allowing sickness funds to contract with individual physicians, thereby weakening the power of the Association of SHI Doctors (cf. Bandelow 2009). The legislation also continued the trend established in previous reforms by increasing co-payments and limiting reimbursement for dental procedures. The SPD-dominated Bundesrat argued unsuccessfully that the proposal required the consent of the Bundesrat, so it had to settle for objecting to the bill. The Bundestag overruled this objection easily with a simple majority.

The change of government in 1998 did little to change the incremental orientation of health care reform, at least in terms of outcomes. The reduction of non-wage labor costs were a political priority, so the newly-elected Red-Green government quickly introduced a modest reform (The Act to Strengthen Solidarity in SHI) aimed at both cost control and softening some of the cuts affecting patients included in the 1997 reform. The legislation required the consent of the SPD-dominated Bundesrat and passed easily.

After the CDU/CSU regained control of the Bundesrat in 1999, however, Red-Green's health reform plans stalled. The Green Party controlled the Health Ministry and quickly announced its intention to maintain quality and reduce costs by reforming key elements of health care governance, including the monopoly of SHI doctors to contract with SHI on volume and reimbursement. The original version of the bill included a budget cap ("global budget") for SHI spending, but this element failed because of CDU/FDP opposition in the Bundesrat. The Bundesrat rejected the 1999 Statutory Health Insurance Act (GKV-Reform 2000), and Red-Green was then forced to rework the proposal so that Bundesrat consent was not necessary. The watered down legislation made modest changes in payments to health care providers, chiefly through DRG payments (see Gerlinger 2002 for details). This debacle led to the replacement of the Green Party Health Minister (Fischer) with one from the SPD (Schmidt).

The SPD-led ministry presided over the adoption of several minor reforms in 2001 that strengthened state regulation of health care costs. However, the 2002 Contribution Stabilization Act threatened to turn into a battle of the chambers when the CDU/CSU dominated Bundesrat claimed its consent was necessary while the government and Bundestag claimed it was not. The Act contained additional cost-cutting measures to stabilize the contribution rate, including a freeze on dental reimbursement levels and slight increases in pharmaceutical rebates. The SPD President of the Bundesrat finally ruled that the legislation did not need Bundesrat consent, and it passed by a simple majority in the Bundestag. 2002 legislation requiring hospitals to adopt DRGs also faced a rocky legislative road. Bundesrat consent was required, and the first version of the legislation failed to muster a Bundesrat majority. Negotiations in the Conciliation Committee (Vermittlungsausschuss) yielded several compromises that facilitated Bundesrat approval.

After several years of conflict with the Bundesrat, the SPD-controlled Health Ministry reached out to the opposition CDU/CSU for a more substantial reform, negotiating the 2004 SHI Modernization Act (GKV-Modernisierungsgesetz). The reform introduces risk-structure compensation, strengthens reference pricing and increases co-payments and user fees. The reform also strengthens state steering of health care by modifying governance structures and weakening the role of the Associations of SHI-approved Physicians. The law allows the establishment of medical care units (Medizinische Versorgungszentren), further weakening the role of the Physicians' Association. The reform also centralized decision-making by establishing the Federal Joint Committee (Gemeinsamer Bundesausschuss) that replaces 
similar actors and which decides on the benefit catalog and approval for new treatments (Bandelow 2009).

The election of the SPD-CDU/CSU grand coalition in 2005 added momentum to reform efforts. One of the most important reforms since 1990 was adopted in 2007: the Act on Strengthening Competition (Wettbewerbsstärkungsgesetz). This law attempts a synthesis of tendencies present in previous reforms that is a potential catalyst for future structural change. Like the Riester Reform, it was adopted after a period of intense electoral competition between the SPD and the CDU (coming to a head in the 2005 electoral campaign) regarding two very different visions for the future health system. The SPD proposed a 'Bürgerversicherung,' (citizens' insurance) which would end the stratification of the insured by occupational groups and the division between public and private health insurance by taxing all forms of income under a consolidated national health insurance plan. The CDU proposal, in contrast, was a premium-based insurance system, (the "Kopfpauschale") which would have ended the family breadwinner model of health insurance, under which spouses and dependents are co-insured. This would have preserved the private insurance market, and dramatically reduced redistribution in the health system, but health insurance subsidies were planned to soften these effects. Both plans would have substantially increased tax revenues for health insurance by decoupling contributions from wages.

As the 2005 election did not produce a decisive winner, the resulting Grand Coalition government prepared a compromise proposal in 2007, which nevertheless introduced some far-reaching changes into the system. The cornerstone of the reform is a common Health Fund (Gesundheitsfonds). Both private and statutory insurance carriers are required to offer a basic insurance package at a fixed price to all applicants regardless of health status. The law also requires compulsory coverage, which did not exist before.

The Health Fund is an important departure from previous practice because all contributions to the statutory sickness funds are now paid into a common fund. A uniform contribution rate also applies across sickness funds, and state financing has increased. The fund distributes monies to the sickness funds based on a risk-adjusted capitation payment for each person insured by a particular fund. Funds that can provide health insurance benefits for less than this capitation rate may reimburse their members; or, in case of deficit, they may levy an income-related additional contribution. These administrative changes are intended to promote cost savings and efficiency because sickness funds now face stronger incentives to compete for members - including chronicallyill or other high-risk patients - and to provide cost-effective services. To this end, the scope for individualized coverage and preferred provider agreements has been increased, while the role of the associations of sickness funds and insurance doctors has decreased. At the same time, the reform also introduced capitation fees for medical providers, which will decrease the relative incomes of ambulatory specialists by comparison to GPs, and has further reduced the role of the corporatist associations previously charged with negotiation physician payments on a collective basis (Jochem 2008; Immergut 2009). The legislation passed easily given concurrent majorities in the Bundestag and Bundesrat.

Reforms adopted since 2007 mark a return to incrementalism in pursuit of cost containment. The CDU/CSU-FDP coalition that governed from 2009 to 2013 legislated minor reforms: 2011 legislation introduces a cap on employer contributions to the statutory health insurance system, balanced by compensation for low-income households. Other legislation modifies pharmaceutical pricing (2011). These reforms reflect the continued concern for controlling non-wage labor costs, as well as the FDP's preference for limiting further intrusions on physician autonomy. The opposition SPD opposed both bills, but they did not require Bundesrat consent, and they were adopted easily.

Table 3 summarizes the political aspects of the reforms discussed in the previous section, as well as their contents. Reforms introduce incremental cuts in the generosity of health provision and limits on payments to providers. At the same time, reform efforts may be seen as incoherent, as they have focused on both increasing market competition and state regulation of the health system. Elements of competition and benefit decreases have been introduced that have significantly 'privatized' health risks, especially for the compulsorily insured, and that aim to increase competitive pressures on providers. In particular, the increasing reliance on budgetary caps for doctors and dentists, stricter regulation of pharmaceutical pricing and caps on prescriptions, and new forms of payment including partial capitation represent a move towards more direct state regulation in the health sector (Gerlinger and Schmucker 2009). At the same time, market mechanisms have been introduced or strengthened, for example, by changes in the relationship between health care providers and sickness funds.

This pattern of reform is decidedly incremental, and it preserves the basic structure of the health care system. Occupational fragmentation remains, and health care providers, especially the Association of SHI Physicians, remain important actors in health care governance, even if the state has asserted its control over central aspects of health care policy. As in pensions, grand coalition bargaining in the context of federal decision-making institutions has had a decisive influence on this incremental pattern of reform. The SPD and CDU/CSU cooperated on the passage of 8 of the 18 reforms analyzed here (Table 3), either as formal coalition partners (2007), informal legislative partners $(1992,2003)$, or during negotiations in the Bundesrat $(1996,2001,2002)$. The seven reforms that did not require Bundesrat consent 
Table 3 Health care reforms since 1988. (Sources: Carrera et al. (2008); ASISP (2012))

\begin{tabular}{|c|c|c|c|c|c|c|}
\hline $\begin{array}{l}\text { Year } \\
\text { enacted }\end{array}$ & Reform & $\begin{array}{l}\text { Parties in } \\
\text { government }\end{array}$ & $\begin{array}{l}\text { Government } \\
\text { majority in } \\
\text { Bundesrat? }\end{array}$ & $\begin{array}{l}\text { Consent } \\
\text { Bundesrat } \\
\text { required? }\end{array}$ & $\begin{array}{l}\text { Both SPD } \\
\& \text { CDU/ } \\
\text { CSU support } \\
\text { reform? }\end{array}$ & Reform content \\
\hline 1988 & $\begin{array}{l}\text { Health Care Reform Law } \\
\text { (Gesundheitsreformgesetz) }\end{array}$ & $\begin{array}{l}\text { CDU/CSU } \\
\& \mathrm{FDP}\end{array}$ & Yes & Yes & No & $\begin{array}{l}\text { Introduction/increase of co-pay- } \\
\text { ments for medical supplies, drugs, } \\
\text { dental care, and inpatient care } \\
\text { Fewer insured drugs }\end{array}$ \\
\hline 1992 & $\begin{array}{l}\text { Health Care Struc- } \\
\text { ture Reform Act } \\
\text { (Gesundheitsstrukturgesetz) }\end{array}$ & $\begin{array}{l}\mathrm{CDU} / \mathrm{CSU} \\
\& \mathrm{FDP}\end{array}$ & No & Yes & Yes & $\begin{array}{l}\text { Higher co-payments and user fees } \\
\text { Mixed-payment system } \\
\text { Budget cap for doctors } \\
\text { Supply of doctors limited } \\
\text { Reference pricing }\end{array}$ \\
\hline 1996 & $\begin{array}{l}\text { Health Insurance Contri- } \\
\text { bution Exoneration Act } \\
\text { (Beitragsentlastungsgesetz) }\end{array}$ & $\begin{array}{l}\mathrm{CDU} / \mathrm{CSU} \\
\& \mathrm{FDP}\end{array}$ & No & Yes & $\begin{array}{l}\text { SPD states } \\
\text { in Bundesrat } \\
\text { agree to law }\end{array}$ & $\begin{array}{l}\text { Co-payments for prescriptions } \\
\text { Modest fee for initial ambulatory } \\
\text { treatment } \\
\text { Higher co-payment for inpatient } \\
\text { care } \\
\text { Lower benefits for spa treatment } \\
\text { Over-the-counter medications no } \\
\text { longer insured }\end{array}$ \\
\hline 1997 & $\begin{array}{l}\text { Second SHI Restructuring Act } \\
\text { (2. GKV-Neuordnungsgesetz) }\end{array}$ & $\begin{array}{l}\mathrm{CDU} / \mathrm{CSU} \\
\& \mathrm{FDP}\end{array}$ & No & No & No & $\begin{array}{l}\text { Budget caps for doctors \& dentists } \\
\text { Morbidity-based compensation for } \\
\text { ambulatory doctors }\end{array}$ \\
\hline 1998 & $\begin{array}{l}\text { Act to Strengthen Solidarity } \\
\text { in SHI (GKV-Solidar- } \\
\text { itätsstärkungsgesetz) }\end{array}$ & $\begin{array}{l}\text { SDP \& } \\
\text { Greens }\end{array}$ & Yes & Yes & No & $\begin{array}{l}\text { Softening of impact of higher } \\
\text { co-payments } \\
\text { Additional reference pricing for } \\
\text { medicines } \\
\text { Mandatory price cuts for } \\
\text { medicines } \\
\text { Rebate sysmtem for drug manu- } \\
\text { facturers and wholesalers }\end{array}$ \\
\hline 1999 & $\begin{array}{l}\text { SHI Reform Act } \\
(\text { GKV-Reform 2000) }\end{array}$ & $\begin{array}{l}\text { SPD \& } \\
\text { Greens }\end{array}$ & No & No & No & $\begin{array}{l}\text { Diagnosis related group (DRG) } \\
\text { payment } \\
\text { Risk structure compensation }\end{array}$ \\
\hline 2001 & $\begin{array}{l}\text { Reference Price } \\
\text { Adjustment Act } \\
\text { (Festbetragsanpassungsgesetz) }\end{array}$ & $\begin{array}{l}\text { SPD \& } \\
\text { Greens }\end{array}$ & No & Yes & $\begin{array}{l}\text { Some CDU } \\
\text { states in } \\
\text { Bundesrat } \\
\text { support } \\
\text { legislation }\end{array}$ & $\begin{array}{l}\text { Shift to reference pricing } \\
\text { Ministerial control of medical } \\
\text { pricing }\end{array}$ \\
\hline 2001 & $\begin{array}{l}\text { Pharmaceutical Budget Aboli- } \\
\text { tion Act (Arzneimittelbudget- } \\
\text { Ablösungsgesetz) }\end{array}$ & $\begin{array}{l}\text { SPD \& } \\
\text { Greens }\end{array}$ & No & Yes & $\begin{array}{l}\text { Some CDU } \\
\text { states in } \\
\text { Bundesrat } \\
\text { support } \\
\text { legislation }\end{array}$ & Additional budget caps for doctors \\
\hline 2002 & $\begin{array}{l}\text { Pharmaceutical Expenditure } \\
\text { Limitation Act (Arzneimitte- } \\
\text { lausgaben-Begrenzungsgesetz) }\end{array}$ & $\begin{array}{l}\text { SPD \& } \\
\text { Greens }\end{array}$ & No & Yes & $\begin{array}{l}\text { Some CDU } \\
\text { states in } \\
\text { Bundesrat } \\
\text { support } \\
\text { legislation }\end{array}$ & $\begin{array}{l}\text { Physicians' budget cap } \\
\text { Mandatory use of generic drugs }\end{array}$ \\
\hline 2002 & $\begin{array}{l}\text { Case Fees Act (Festbetrags- } \\
\text { Anpassungsgesetz) }\end{array}$ & $\begin{array}{l}\text { SPD \& } \\
\text { Greens }\end{array}$ & No & Yes & $\begin{array}{l}\text { Some CDU } \\
\text { states in } \\
\text { Bundesrat } \\
\text { support } \\
\text { legislation }\end{array}$ & DRG payments \\
\hline
\end{tabular}


Table 3 (continued)

\begin{tabular}{|c|c|c|c|c|c|c|}
\hline $\begin{array}{l}\text { Year } \\
\text { enacted }\end{array}$ & Reform & $\begin{array}{l}\text { Parties in } \\
\text { government }\end{array}$ & $\begin{array}{l}\text { Government } \\
\text { majority in } \\
\text { Bundesrat? }\end{array}$ & $\begin{array}{l}\text { Consent } \\
\text { Bundesrat } \\
\text { required? }\end{array}$ & $\begin{array}{l}\text { Both SPD } \\
\& \text { CDU/ } \\
\text { CSU support } \\
\text { reform? }\end{array}$ & Reform content \\
\hline 2002 & $\begin{array}{l}\text { Contribution Rate } \\
\text { Stabilization Act } \\
\text { (Beitragssatzsicherungsgesetz) }\end{array}$ & $\begin{array}{l}\text { SPD \& } \\
\text { Greens }\end{array}$ & No & No & No & Reference pricing \\
\hline 2002 & $\begin{array}{l}\text { DRG Law for Hospitals } \\
\text { (Gesetz zur Einführung } \\
\text { des diagnose-orientierten } \\
\text { Fallpauschalensystems } \\
\text { für Krankenhäuser) } \\
\text { (Fallpauschalengesetz-FPG) }\end{array}$ & $\begin{array}{l}\text { SPD \& } \\
\text { Greens }\end{array}$ & No & Yes & $\begin{array}{l}\text { Some CDU } \\
\text { states in } \\
\text { Bundesrat } \\
\text { support } \\
\text { legislation }\end{array}$ & DRG Payment \\
\hline 2003 & $\begin{array}{l}\text { SHI Modernization Act } \\
\text { (GKV-Modernisierungsgesetz) }\end{array}$ & $\begin{array}{l}\text { SDP \& } \\
\text { Greens }\end{array}$ & No & Yes & $\begin{array}{l}\text { CDU/CSU } \\
\text { support at } \\
\text { early stage }\end{array}$ & $\begin{array}{l}\text { Co-payments and user fees } \\
\text { Modest reduction in benefits } \\
\text { Reference pricing } \\
\text { Reimbursement of out-patient care } \\
\text { in EU } \\
\text { Risk-structure compensation } \\
\text { Increase in use of health technol- } \\
\text { ogy assessments }\end{array}$ \\
\hline 2007 & $\begin{array}{l}\text { Law to strengthen competi- } \\
\text { tion between SHIs (GKV- } \\
\text { Wettbewerbsstärkungsgesetz } \\
\text { GKV-WSG) }\end{array}$ & $\begin{array}{l}\text { SDP \& } \\
\text { CDU/CSU }\end{array}$ & Yes & Yes & Yes & $\begin{array}{l}\text { Pooling of SHI contributions } \\
\text { in a central "Health Fund" } \\
\text { (Gesundheitsfonds) } \\
\text { Uniform contribution rates across } \\
\text { SHI funds; supplementary pre- } \\
\text { miums for funds with insufficient } \\
\text { revenue from the central fund } \\
\text { Insurance mandatory for all }\end{array}$ \\
\hline 2010 & $\begin{array}{l}\text { Law on the Change of the SHI } \\
\text { (GKV-Änderungsgesetz } \\
G K V-\ddot{A n} n d G)\end{array}$ & $\begin{array}{l}\mathrm{CDU} / \mathrm{CSU} \\
\& \mathrm{FDP}\end{array}$ & Yes & No & No & $\begin{array}{l}\text { Obligatory discounts on drugs, and } \\
\text { price freeze until } 2013 \\
\text { Employer SHI contribution share } \\
\text { frozen at } 7.3 \%\end{array}$ \\
\hline 2011 & $\begin{array}{l}\text { Law on Financing the SHI } \\
\text { (GKV-Finanzierungsgesetz } \\
\text { GKV-FinG) }\end{array}$ & $\begin{array}{l}\mathrm{CDU} / \mathrm{CSU} \\
\& \mathrm{FDP}\end{array}$ & No & No & No & $\begin{array}{l}\text { Contributions to SFs increased } \\
\text { (from } 14.9 \text { to } 15.4 \% \text { in } 2011 \text { ) } \\
\text { Employers' share of contribu- } \\
\text { tions frozen at } 7.3 \% \text { of qualifying } \\
\text { income } \\
\text { Compensation for low-income } \\
\text { households } \\
\text { Modest reduction in cost index- } \\
\text { ation for hospitals }\end{array}$ \\
\hline 2011 & $\begin{array}{l}\text { Law on the Re-organisation of } \\
\text { the Market for Pharmaceuti- } \\
\text { cals (Gesetz zur Neuordnung } \\
\text { des Arzneimittelmarktes } \\
\text { AMNOG) }\end{array}$ & $\begin{array}{l}\mathrm{CDU} / \mathrm{CSU} \\
\& \mathrm{FDP}\end{array}$ & No & No & No & $\begin{array}{l}\text { Modified reference pricing for } \\
\text { new drugs }\end{array}$ \\
\hline 2012 & $\begin{array}{l}\text { Law on Health Care Structure } \\
\text { (GKV-Versorgungsstrukturge- } \\
\text { setz GKV-VStG) }\end{array}$ & $\begin{array}{l}\mathrm{CDU} / \mathrm{CSU} \\
\& \mathrm{FDP}\end{array}$ & No & No & No & $\begin{array}{l}\text { Adjustment in policies affecting } \\
\text { supply of doctors } \\
\text { Increase in ways that SFs can dif- } \\
\text { ferentiate their services }\end{array}$ \\
\hline
\end{tabular}

were also shaped by informal grand coalition bargaining, because they often began their legislative life as proposals requiring Bundesrat consent, but after rejection in the Upper Chamber, they were reformulated (and weakened) in order to escape Bundesrat consent (1999) or they were designed at the outset to circumvent the Bundesrat. The 2005 Federalism Reform modestly reduced the proportion of legisla- tion requiring Bundesrat consent, facilitating the passage of reforms after 2010 (Zolnhöfer 2008).

3.3 Increasing inequalities in health care and pensions

The last 2 decades of health care reform have resulted in a rising financial burden for private households. One of 
the most important tools for cost containment has been to increase copayments for pharmaceuticals, medical supplies, dental care and hospital stays. These measures have increased private households' and nonprofit organizations' share of the overall costs of the system. As the figure below shows, in 1992 private households paid about $11 \%$ of total healthcare spending. Between 1995 in 2005, this share increased to about $14 \%$, and it has been stable since then. The main cause for this increase was the removal of several kinds of medical coverage from the national list of covered services for the sickness funds (GKV-Leistungskatalog) (Müller and Boehm 2009, p. 16).

Pension reforms will also lead to growing inequalities. As noted above, only individuals who voluntarily buy individual pension contracts or who are covered by an occupational pension plan will have roughly the same income replacement that the pre-2001 system offered. Given the increase in atypical employment and the tendency of lowincome and atypical workers to not buy individual pension coverage, the retirement income gap between those in fulltime, standard employment and those in atypical employment is likely to increase. In addition, Bridgen and Meyer (2014) find that even standard workers in key sectors will experience significant drops in income in retirement (see also Hinrichs 2012).

As we have seen, however, the politics of the middle way has already resulted in some corrections to these trends, and may well do so in future.

\section{Conclusion}

This article argues that the development of German social policy since the late 1980s shows remarkable continuity, both in terms of the pattern of policy-making and in terms of program structure. The trajectory of policy change in the pension and health care system has been a process of ongoing recalibration of highly institutionalized policies. Analysis of the political forces shaping these reforms suggests that the "grand coalition state" is still an apt characterization of social policymaking in Germany. Political institutions continue to create very strong incentives for the two major parties to compromise on social policy. This, no doubt, explains much of the incremental nature of reforms since 1990. This does not mean that the parties agree on the basic principles of social policy development. Indeed, both the SPD and the $\mathrm{CDU} / \mathrm{CSU}$ have made their social policy differences very clear in election campaigns and parliamentary bargaining. Thus the paradox of social policy development since 1990 is that electoral grandstanding has increased because the parties compete for votes in a much more competitive environment. Nevertheless, formal and informal grand coalition bargaining continues to rule the day.
In contrast to many contributions to the literature on the transformation of the German welfare state, this article emphasizes the continuing influence of conservative principles on the direction of change. Liberalization is certainly a central aspect of reform processes, but this liberalization has not strongly challenged several core conservative principles: occupational fragmentation and family-based benefit entitlement. In other words, pension and health benefits have been reduced, but this has occurred within the basic structure of conservative welfare statism, and has been counter-balanced by compensatory mechanisms. There is one exception to this trend: reforms significantly weaken the effectiveness of the insurance principle in pensions. Incremental cost-cutting measures, especially in the pension system, will result in significantly lower average pensions for future retirees. Likewise, the strengthening of market principles in the health care system will lead to higher costs for low-income groups.

The analysis presented here also casts doubt on industrial relations as a key driver of welfare state reform. To be sure, the structure of health care and pension financing (via payroll contributions) was a central target of reform, because of pressure on non-wage labor costs. Unions, and, especially, employers lobbied for cost control in both programs, but this has been a constant feature of German welfare politics in the post-war period. Moreover, non-wage labor costs remain high in European perspective: in 2014 the combined (employer and employee) social insurance contribution rate was $38.9 \%$ of qualifying wages (this includes pensions, health care, care insurance and unemployment insurance). Employees pay a slightly larger share of obligatory contributions ( 0.9 percentage points in health care) than employers, but this hardly amounts to an overwhelming victory for employers. Indeed, union and employer bargaining in corporatist channels was not an important influence on reform processes. Unions and employers certainly lobbied political actors in pursuit of their preferred policies, but neither got much of what it wanted. Moreover, governments have shown their willingness to press forward with reforms opposed by either unions, employers, or both. This is particularly true in pensions: unions vigorously opposed the 2001 reform, while employers argued it did not go far enough. The situation was reversed in 2013 when unions welcomed, and employers opposed, the re-introduction of early retirement for workers with 45 years of service.

Esping-Andersen's discussion of the conservative welfare regime was always ambivalent; he never seemed to be able to decide whether the proper label was "conservative", "corporatist" or "Christian Democratic." My analysis highlights instead the continuing relevance of the social market welfare state based on implicit grand coalition agreements between the SPD and the CDU/CSU. Despite, first, Conservative and then later Christian Democratic dominance, the 
German welfare state never represented a coherent conservative vision of society. Instead, institutional features introduced through historical contingencies gained a modicum of coherence as societal stakeholders and corporatist bodies adapted and used these institutions in a process of historical bricolage. Over time, institutional adaption has been accomplished through a series of bi-partisan compromises that have bridged fundamental disagreements about the role of the state and the degree of preferred redistribution. Some of these agreements - such as the change from gross to net wage indexation in 1987 in pensions or the introduction of risk-compensation to health insurers - have provided the basis for significant change. Whether recent efforts to bring about change through reforms of governance structures will prove to be ultimately successful will depend upon whether current and future political compromises intensify or truncate these measures.

\section{References}

Alber, J.: Vom Armenhaus zum Wohlfahrtsstaat: Analysen zur Entwicklung der Sozialversicherung in Westeuropa. Campus Verlag, Frankfurt a. M. (1982)

Alber, J.: Der Sozialstaat in der Bundesrepublik 1950-1983. Campus Verlag, Frankfurt a. M. (1989)

Alber, J.: Das Gesundheitswesen der Bundesrepublik Deutschland: Entwicklung, Struktur und Funktionsweise. Campus, Frankfurt a. M. (1992)

Anderson, K.M., Meyer, T.: "Social democracy, unions, and pension politics in Germany and Sweden". J. Public. Policy. 23(1), 23-54 (2003)

Anderson, K.M., Meyer, T.: "New social risks and pension reform in Germany and Sweden. The politics of pension rights for childcare". In: Armingeon, K., Bonoli, G. (eds.) The Politics of PostIndustrial Welfare States. Routledge, London (2006)

ASISP: Germany. Annual National Report 2012. Pensions, Health Care and Long-term Care. European Commission DG Employment, Social Affairs and Inclusion (2012)

Bandelow, N.C.: Health governance in the aftermath of traditional corporatism: One small step for the legislator, one giant leap for the subsystem? Ger. Policy. Stud. 5(1), 45-63 (2009)

Bridgen, P., Meyer, T.: The liberalisation of the German social model: Public-private pension reform in Germany since 2001. J. Soc. Policy. 43(1), 37-68 (2014)

Bundesministerium fuer Arbeit und Soziales: Ergänzender Bericht der Bundesregierung zum Rentenversicherungsbericht 2012 gemäß $\S 154$ Abs. 2 SGB VI (Altersversicherungsbericht 2012) (2013)

Carrera, P., Siemens, K., Bridges, J.: Health care financing reforms in Germany: The case for rethinking the evolutionary approach to reforms. J. Health. Polit. Policy. Law. 33(5), 979-1005 (2008)

Daly, M.: The Gender Division of Welfare: The Impact of the British and GermanWelfare States. Cambridge University Press, Cambridge (2000)

Esping-Andersen, G.: The Three Worlds of Welfare Capitalism. Princeton University Press, Princeton (1990)

Estevez-Abe, M., Iversen, T., Soskice, D.: "Social protection and the formation of skills: A reinterpretation of the welfare state". In: Hall, P., Soskice, D. (eds.) Varieties of Capitalism: The Institutional Foundations of Comparative Advantage, pp. 145-183. Oxford University Press, Oxford (2001)
Gerlinger, T.: Zwischen Korporatismus und Wettbewerb: gesundheitspolitische Steuerung im Wandel. Veröffentlichungsreihe der Forschungsgruppe Public Health, Wissenschaftszentrum Berlin für Sozialforschung (WZB), No. P02-204 (2002)

Gerlinger, T., Schmucker, R.: A long farewell to the Bismarck system: Incremental change in the German health insurance system. Ger. Policy. Stud. 5(1), 3-20 (2009)

Hall, P., Soskice, D.: Varieties of Capitalism. Oxford University Press, Oxford (2001)

Häusermann, S.: The Politics of Welfare State Reform in Continental Europe. Modernization in Hard Time. Cambridge University Press, Cambridge (2010)

Hinrichs, K.: Germany: A flexible labour market plus pension reforms means poverty in old age. In: Hinrichs, K., Jessoula, M. (eds.) Labour Market Flexibility and Pension Reforms, pp. 29-61. Palgrave, Basingstoke (2012)

Hockerts, H.G.: Der deutsche Sozialstaat. Entfaltung und Gefährdung seit 1945. Vandenhoeck \& Ruprecht, Göttingen (2011)

Howell, C.: Varieties of capitalism: and then there was one? Comp. Polit. 36(1), 103-124 (2003)

Immergut, E.M.: Le système de santé allemand: impasse ou revolution?. In: Kervasdoué, J. de. (ed.) Carnet de Santé de la France 2009, pp. 135-154. Dunod, Mutualité Française, Paris (2009) (J. d. Kervasdoué, Trans.)

Jochem, S.: Germany: The public-private dichtomy in the Bismarckian welfare regime. In: Beland, D., Gran, B. (eds.) Social Policy Puzzles. Reconsidering the Public-Private Dichotomy for Health and Pension Policies, pp. 190-206. Palgrave, New York (2008)

Jochem, S.: Reformpolitik im Wohlfahrtsstaat: Deutschland im internationalen Vergleich. Lit-Verlag, Münster (2009)

Katzenstein, P.: Germany: The Semi-Sovereign State. Temple University Press, Philadelphia (1987)

Manow, P., Seils, E.: Adjusting badly. The German welfare state, structural change, and the open economy. In: Scharpf, F.W., Schmidt, V.A. (eds.) Welfare and Work in the Open Economy, Vol. II: Diverse Responses to Common Challenges, pp. 264-307. Oxford University Press, Oxford (2000)

Meyer, T.: Beveridge statt Bismarck! Friedrich Ebert Stiftung, Berlin (2013)

Müller, M., Böhm, K.: Ausgaben und Finanzierung des Gesundheitswesens. Gesundheitsberichterstattung des Bundes, Heft 45. Robert Koch-Institut, Berlin (2009)

Nullmeier, F., Rüb, F. Die Transformation der Sozialpolitik: Vom Sozialstaat zumSicherungsstaat. Campus Verlag, Frankfurt a. M. (1993)

Palier, B., Thelen, K.: Institutionalizing dualism: Complementarities and change in France and Germany. Polit. Soc. 38(1), 119-148 (2010)

Perschke-Hartmann, C.: Die doppelte Reform: Gesundheitspolitik von Blüm zu Seehofer. Springer, Wiesbaden (1994)

Pierson, P.: Dismantling the Welfare State. Reagan, Thatcher, and the Politics of Retrenchment. Cambridge University Press, Cambridge (1994)

Scharpf, F.W.: The joint decision trap: Lessons from German federalism and European integration. Public. Admin. 66, 239-278 (1988)

Schludi, M.: The Reform of Bismarckian Pension Systems. Amsterdam University Press, Amsterdam (2005)

Schmidt, M.G.: West Germany. The policy of the middle way. J. Public. Policy. 7, 135-177 (1987)

Schulze, I., Jochem, S.: Germany: Beyond policy gridlock in Immergut E., Anderson K., Schulze, I. Handbook of West European Pension Politics, pp. 660-711. Oxford University Press, Oxford (2007)

Stone, D.A.: The Limits of Professional Power. National Health Care in the Federal Republic of Germany. The University of Chicago Press, Chicago (1980) 
Streeck, W.:Re-Forming Capitalism. Oxford University Press, Oxford (2007)

Trampusch, C.: Der erschöpfte Sozialstaat: Transformation eines Politikfeldes. Campus Verlag, Frankfurt a. M. (2009)

Vail, M.: Recasting Welfare Capitalism. Economic Adjustment in Contemporary France and Germany. Temple University Press, Philadelphia (2009)

Volkens, A., Lehmann, P., Matthieß, T., Merz, N., Regel, S., Werner, A.: The Manifesto Data Collection. Manifesto Project (MRG/ CMP/MARPOR). Version 2015a. Wissenschaftszentrum Berlin für Sozialforschung (WZB), Berlin (2015)

Von Winter, T.:Sozialpolitische Interessen: Konstituierung, politische Repräsentation und Beteiligung an Entscheidungsprozessen. Nomos, Baden-Baden (1997)

Zolnhöfer, R.: An end to the reform logjam? The reform of German federalism and economic policy-making. Ger. Polit. 17(4), 457469 (2008)

Zolnhöfer, R.: Wirtschaftspolitische Gesetzgebung nach der Föderalismusreform I: Schluss mit dem Reformstau? In: Schrenk, K.H., Soldner M. (eds.) Analyse demokratischer Regierungssysteme, pp. 389-400. Verlag für Sozialwissenschaften, Wiesbaden (2010)
Karen M. Anderson ist außerordentliche Professorin für Sozialpolitik an der Universität Southampton. Sie promovierte in Politikwissenschaft an der Universität von Washington (Seattle) und war in verschiedenen Funktionen an den niederländischen Universitäten Radboud Nijmegen, Leiden und Twente tätig. Der Schwerpunkt ihrer Forschung liegt auf vergleichender Entwicklung in der Sozialpolitik, der Interaktion von Arbeitsmarkt- und Sozialpolitik und den Auswirkungen der Europäisierung auf nationale Wohlfahrtsstaaten. Sie ist die Autorin von Social Policy in the European Union (Palgrave, 2015) und Herausgeberin (zusammen mit Ellen M. Immergut und Isabelle Schulze) des Handbook of West European Pension Politics (Oxford University Press, 2007). Ihre Werke erschienen auch in der Comparative Political Studies, Comparative Politics, Zeitschrift für Sozialreform, West European Politics, Canadian Journal of Sociology, und dem Journal of Public Policy. 